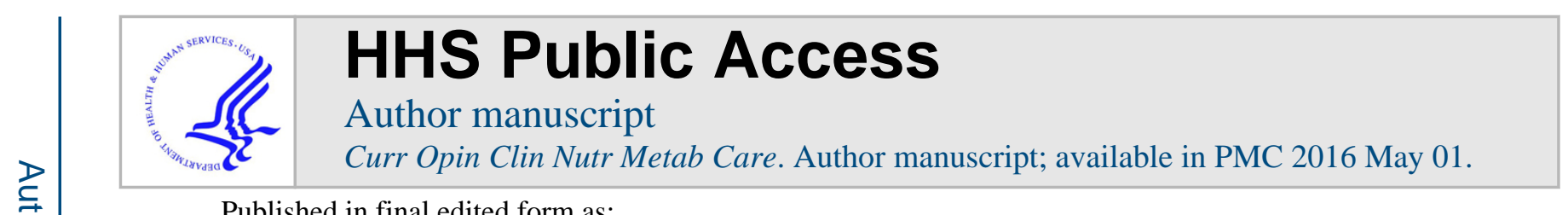

Published in final edited form as:

Curr Opin Clin Nutr Metab Care. 2015 May ; 18(3): 248-253. doi:10.1097/MCO.0000000000000162.

\title{
Protein Intake and Muscle Function in Older Adults
}

Rachel R. Deer ${ }^{1}$ and Elena Volpi ${ }^{1,2,3}$

${ }^{1}$ Sealy Center on Aging, University of Texas Medical Branch, Galveston, TX

${ }^{2}$ Department of Internal Medicine, University of Texas Medical Branch, Galveston, TX

${ }^{3}$ Department of Nutrition and Metabolism, University of Texas Medical Branch, Galveston, TX

\section{Abstract}

Purpose of review-We provide an update on the recent advances in nutrition research regarding the role of protein intake in the development and treatment of sarcopenia of aging.

Recent findings-Specific muscle mass, strength and function cutpoints for the diagnosis of sarcopenia have been identified. There is mounting evidence, as highlighted by multiple consensus statements, that the RDA $(0.8 \mathrm{~g} / \mathrm{kg} \mathrm{BW})$ may be inadequate to promote optimal health in older adults. Recent research also indicates that in addition to total daily protein intake also the timing of protein intake is important to best stimulate muscle protein synthesis and maintain muscle mass and function in older adults.

Summary-Recent evidence suggests that the RDA for protein is inadequate and that the timing and distribution of protein consumption throughout daily meals may be as important as the total quantity. Research has continued to advance our understanding of protein's effects on muscle metabolism; however, there remains a need for large, long-term, randomized clinical trials examining whether the positive effects of dietary protein on muscle metabolism seen in acute studies will translate over the long term into gains of muscle mass, function, and overall health of older adults.

\section{Keywords}

aging; sarcopenia; muscle strength; nutrition; dietary protein

\section{Introduction}

As the older population ( $>65$ years) continues to expand, the progressive loss of muscle mass and function with advancing age is becoming a greater concern. This condition, sarcopenia, is characterized by a gradual loss in skeletal muscle mass, strength and function; and contributes substantially to frailty, disability, physical dependence and mortality in older adults. Nutritional interventions, using protein supplementation, have been shown to have

Corresponding Author: Elena Volpi, 301 University Blvd., Galveston, TX 77555-0177, evolpi@utmb.edu, 408-772-1977.

Conflicts of interest

The authors declare that they do not have any conflicts of interest. 
beneficial effects on muscle health. This brief review summarizes the current state of research regarding protein intake and skeletal muscle function in older adults.

\section{Loss of skeletal muscle mass and strength with aging (Sarcopenia)}

Sarcopenia is an extremely common clinical problem that is estimated to occur in at least one in 20 community-dwelling individuals, and as high as one in three in institutionalized frail older adults $(1,2)$. With advancing age, there is a loss of skeletal muscle strength and function, which affects physical performance and activities of daily living. This loss of strength is usually associated with decreased muscle mass or muscle quality. Debate is ongoing as how to best define and diagnose sarcopenia. Numerous operative definitions have been published by international consensus panels over the past few years (2-5). The absence of a standard definition makes it difficult to determine the prevalence of sarcopenia and to compare the outcomes of clinical trials. Thus research into the discovery of sarcopenia's causes and possible treatments has been hindered.

In order to address the existing inconsistencies, a set of articles was published earlier this year by the Foundation for the National Institutes of Health (FNIH) Sarcopenia group (3, 610). This series of articles used pooled data of primarily healthy older adults from a number of large cohort studies and clinical trials to provide evidence-based cutpoints for the diagnosis of sarcopenia. While this is a huge step in the right direction, additional research needs to be carried out to evaluate the specific contributions of skeletal muscle mass and function as it relates to functional outcomes. These thresholds should also be validated in more vulnerable older populations (with acute or chronic diseases, multiple comorbidities, etc).

Sarcopenia is of great clinical interest because it has been shown to predict loss of independence, falls, and mortality. Recently, several studies have indicated that muscle strength and function effectively predicted mobility decline, disability and mortality $(9,11$, 12). The FNIH sarcopenia project found that low grip strength and low lean mass strongly predicted incident mobility impairment (9). A recent analysis of the Aging and Longevity Study, a prospective cohort study in community-dwelling frail older adults (80-85 y) from the Sirente area evaluated the impact of sarcopenia on the risk of all-cause death (11). Twenty-two percent of subjects were found to have sarcopenia. Over the 7-yr follow-up period, participants with sarcopenia had a higher risk of death for all causes (67\% vs 41\%) as compared to non-sarcopenic subjects (11).

Therefore, it is important to identify clinical therapeutic interventions that are able to promote muscle mass and function in older adults. While exercise is a well-known tool to improve muscle mass and function $(2,13-15)$, in older adults the capacity and/or ability to exercise is often limited. Malnutrition and undernutrition are also important contributing factors to sarcopenia (16-20). Thus, nutritional interventions represent an important option to preserve muscle mass and function. 


\section{Protein recommendations for older adults}

It is important to note that protein is the only macronutrient that does not have an inactive compound to serve as a reservoir and thus dietary amino acids must be incorporated into functional proteins. Skeletal muscle contractile proteins are the largest protein reservoir that respond anabolically to feeding and can be rapidly utilized to supply amino acids to the entire organism during fasting or stress. Insufficient protein intake to satisfy daily requirements leads to negative protein balance and results in skeletal muscle atrophy, impaired muscle growth, and functional decline. Therefore, it is important that the proper amount of protein is consumed to prevent muscle wasting and maintain skeletal muscle mass and function.

\section{What is the current recommendation for protein intake?}

The Recommended Dietary Allowance (RDA) is set to provide a sufficient quantity of a particular nutrient to prevent deficiency in the majority of the population. Currently, the RDA for protein ( $0.8 \mathrm{~g}$ protein $/ \mathrm{kg}$ of body weight/day) is the same for all adults, regardless of age or sex. The Estimated Average Requirement (EAR) is the average daily nutrient intake level to meet the requirements of half of the healthy individuals for protein for adults $(0.66 \mathrm{~g} / \mathrm{kg} \mathrm{BW} /$ day). In addition, the acceptable macronutrient distribution range (AMDR) specifies that protein should represent $10-35 \%$ of an individual's total daily energy intake. Interestingly, the RDA typically falls in the lower AMDR range (10-15\%) for most adults.

The EAR and RDA recommendations were made based on studies using nitrogen-balance as a proxy for protein synthesis. EAR is calculated using this methodology to be the average minimal amount of protein (nitrogen) intake to balance nitrogen excretion. In theory, if intake matches excretion there will be no change in protein levels in the body over time. It is important to note that nitrogen-balance studies are highly controlled, time-consuming and difficult to run. Thus very few well-designed studies have been conducted. The results from the few studies done in older adults are conflicting, with some supporting the current protein RDA (21) and others indicating that higher intakes are necessary to prevent nitrogen loss (22). An alternative method, the indicator amino acid oxidation technique, uses labeled tracer oxidation measured in expired air in response to different amounts of protein to determine the average minimal amount of protein necessary for nitrogen balance. Two recent studies using this technique found that adults aged 65 and older require protein intakes greater than the current RDA $(23,24)$. These studies are supported by recent consensus reports that concluded that the current protein recommendation for older adults is too low and that older adults should consume 1.0-1.2 $\mathrm{g} / \mathrm{kg} \mathrm{BW} /$ day (25-28) for optimal health.

\section{How much protein do older adults actually consume?}

While many adults consume protein at or above the RDA, a significant proportion of older adults are consuming levels much lower than the RDA (25). Data from the National Health and Nutrition Examination Survey (NHANES) 2005-2006 showed that 20-24\% of older women and 5-12\% of older men consumed less protein than the EAR of $0.66 \mathrm{~g} / \mathrm{kg} \mathrm{BW} /$ day (29). Thus, considering that the EAR is the mean protein intake sufficient for half of the 
healthy population, an even greater proportion of the aging population is at risk of inadequate protein intake.

\section{Why do older adults require more protein than younger individuals?}

The original RDA recommendations were made based on studies conducted in young healthy adults and do not take into account the many physiological changes that occur with aging. Additionally, these recommendations were based on the concept of preventing deficiency as opposed to promoting optimal health, which may be of greater importance in the elderly. There is mounting evidence that older adults need more dietary protein than their younger counterparts to support good health, promote recovery from illnesses, and maintain functionality.

The most common age-related causes of protein shortfall are inadequate intake of dietary protein (loss of appetite, gastrointestinal issues, reduced energy need, changes in food preference), a reduction in the utilization of available protein (anabolic resistance, insulin resistance, higher splanchnic extraction), and a higher basal requirement (acute and chronic diseases, inflammatory disease, increased oxidation of protein) (11, 25, 26, 30-34).

\section{What amount of protein is needed to stimulate muscle protein synthesis in older adults?}

Muscle growth is dependent upon protein consumption and the accompanying hyperaminoacidemia, which stimulates a marked rise in muscle protein synthesis (MPS) and a mild suppression of muscle protein breakdown. Insufficient protein intake to satisfy daily requirements leads to a persistently negative protein balance (MPS is less than MPB) and results in skeletal muscle atrophy, impaired muscle growth, and functional decline. Thus, it is important to understand the quantity of protein that is necessary to optimally stimulate MPS in older adults in order to replenish the amino acids lost during fasting and stress.

Many metabolic studies have demonstrated that utilization of dietary amino acids for MPS is blunted or impaired in healthy older adults as compared to younger individuals. This anabolic resistance can be overcome by higher levels of protein/amino acid intake $(14,32)$. Recently, multiple studies have indicated that 25-30 g of a high quality protein is necessary to reach the threshold for maximal stimulation of MPS in older adults $(28,33,35-37)$.

\section{Is the meal pattern important for optimal utilization of dietary protein?}

The total quantity of protein consumed daily is important, but recent research indicates that the distribution of dietary protein throughout the day's meals is just as important. For example, older Americans tend to consume a skewed meal pattern with the majority of protein intake occurring during the evening meal. The NHANES 2005-2006 survey data found that women $>51 \mathrm{y}$ consumed $11-12 \mathrm{~g}$ of protein with breakfast, $15-18 \mathrm{~g}$ at lunch, 27$30 \mathrm{~g}$ at dinner and an additional $6-7 \mathrm{~g}$ as snacks. Older men (>51) had a similarly skewed intake patterns (breakfast: 15-16g, lunch: 18-23g, dinner: 34-44g, snack: 7-11g).

Three studies recently examined the anabolic efficacy of the quantity and distribution of protein throughout the day in elders. The first study is a cross-sectional analysis examining dietary patterns of German adults grouped into frail, pre-frail, and non-frail (38). 
Interestingly, daily protein intake was similar in all groups $(1.07 \mathrm{~g} / \mathrm{kg} \mathrm{BW} /$ day $)$, but the distribution varied by group. Those in the non-frail group had evenly distributed protein throughout the day while pre-frail and frail groups ate a more skewed distribution of protein with higher protein consumption at lunch (38). Consumption of an uneven distribution of protein was associated with frailty, slower walking speed, and fatigue (38).

The second study, a randomized clinical trial in hospitalized adults aged 85 years and older, grouped individuals into two diets that differed in the distribution of protein during 4 meals each day (39). The spread protein diet had relatively evenly distributed protein over the course of 4 meals (breakfast 12.2: lunch 21.0: snack 13.5: dinner $21.1 \mathrm{~g}$ ); while, the pulse protein diet had a larger dose of protein at noon (4.5: 47.8: 2.3: $10.9 \mathrm{~g})$. In this study patients that were provided the pulse diet had significant increases in lean mass as compared to those on the spread diet (39).

While the results of these two studies seem contradictory at first, the amount of protein (12$21 \mathrm{~g}$ ) in each of the spread diet meals may not have been adequate to maximally stimulate muscle protein synthesis (MPS). Thus, subjects consuming the spread diet did not meet the threshold to maximally stimulate MPS at any of the 4 meals during the day, yet those in the pulse diet had one large dose of protein ( $48 \mathrm{~g}$ ) capable of eliciting a robust anabolic response $(25,28)$.

In agreement with this concept, the third study conducted in healthy middle aged adults found that a diet providing enough protein $(30 \mathrm{~g})$ to maximally stimulate MPS at each meal (breakfast, lunch and dinner) induced the largest 24-hour MPS when compared to the same amount of daily protein $(90 \mathrm{~g})$ taken in a skewed pattern (breakfast: $10.7 \mathrm{~g}$, Lunch: $16 \mathrm{~g}$ : dinner: $63.4 \mathrm{~g}$ ), in which only the dinner contained enough protein to maximally stimulate MPS (35).

Collectively these data indicate that both the total daily protein and the patterns of intake are important to maximally stimulate MPS and maintain muscle mass and function in older adults.

\section{Is there evidence that protein intake is associated with functional outcomes in older adults?}

Numerous long-term observational studies examining the association of dietary protein intake with body composition and functional outcomes have shown that protein intake is positively associated with preservation of lean mass in older adults (40-44). The Health, Aging and Body Composition (Health $\mathrm{ABC}$ ) cohort study found that over a 3 year observation period lower protein intake was associated with larger loss of lean body mass (40). Consistently, another prospective cohort study using a subset of data from the Women's Health Initiative found that higher protein intake is associated with a reduction in the loss of muscle strength and function (41).

A recent prospective, nested case-control study of healthy, community-dwelling adults aged 70 years and older found that the odds ratio of unhealthy weight loss in participants with low protein intake $(<0.8 \mathrm{~g} / \mathrm{kg} \mathrm{BW} /$ day) was 2.56 compared with participants with high protein 
intakes (>1.2 g/kg BW/day). These results suggest that protein intakes $>1.0 \mathrm{~g} / \mathrm{kg} \mathrm{BW} /$ day were protective against harmful weight loss in healthy elders (43). A 6-year longitudinal observational study of a subset of women in the Women's Health Initiative population found that higher protein intake was associated with better physical function and with slower rates of functional decline in postmenopausal women (42). In agreement with these findings, a cross-sectional observational analysis of the relationship between dietary protein on body composition and physical performance in older women aged 60-90 years. Subjects were grouped based on protein consumption (below RDA= low protein, above RDA= high protein). Women in the high protein group had lower body mass, higher upper and lower extremity strength, higher SPPB score, and higher PPT score (indicating higher muscle strength and physical function) (44).

Although these finding are based on associations, they lend further evidence to suggest that older adults might benefit from higher protein intake than the current RDA.

\section{Can we improve muscle mass and function in older adults by increasing protein intake?}

A few intervention studies have been conducted to further examine the effects of protein intake on muscle mass and physical function. A recent long term study in middle aged adults (45-60 years old) found that subjects consuming high protein meals $(\sim 35 \%)$ more frequently (6x/day) had lower abdominal fat and higher lean body mass as compared to subjects consuming a more traditional dietary protein intake (45). Similar findings were reported in a recent meta-analysis in which subjects with higher protein diets $(25-32 \%)$ had the greatest weight loss (46). A third study in community-dwelling overweight middle aged adults found that higher protein diets $(1.4 \mathrm{~g} / \mathrm{kg} \mathrm{BW} /$ day $)$ allowed for maintenance of lean body mass during weight loss as compared to diets based on the protein RDA (0.8 g/kg BW/day) (47). These studies suggest that high protein diets are beneficial in maintaining lean body mass during weight loss.

Recently, a 6-month intervention in mobility-limited older adults (70-85y) indicated that protein supplementation (whey protein concentrate, $20 \mathrm{~g}$ twice daily) in combination with resistance exercise tended to cause greater increases in lean body mass, mid-thigh cross sectional area, and muscle strength as compared to exercise plus an isocaloric non-protein supplement (13). These differences did not reach statistical significance perhaps due to high variability in responses and low compliance.

A 12-week clinical trial in community-dwelling frail older adults examined the effects of protein supplementation ( $25 \mathrm{~g}$ twice daily) on physical function. In agreement with the previous study, subjects in the protein supplement group had significant improvements in physical function (increase in physical function test, stable SPPB, improvement in gait speed) as compared to the control group (48). When taken together these studies support the notion that protein is beneficial in improving muscle mass and function in older adults.

\section{Conclusions}

Sarcopenia is a common clinical problem in older adults. Historically, research in this area has been hindered by the lack of a clear definition of sarcopenia. Evidence-based cutpoints 
recently published by the FNIH for the diagnosis of sarcopenia will allow for better coordination and comparison of future studies. While exercise remains a fundamental tool for maintenance of muscle mass and function with aging, nutritional interventions involving protein intake patterns and supplementation have emerged as important approaches to managing sarcopenia. Research has continued to advance our understanding of protein's effects on muscle metabolism, however many questions remain. Should we increase the RDA for older adults, and to what level? How can we incorporate in the RDA the evidence that daily protein intake patterns significantly impact dietary protein retention? How do we adjust protein intakes for ill older adults, considering that the RDA is specifically set for all healthy adults (yet most older adults have at least one chronic disease)? Will the findings from recent acute studies indicating that $20-30 \mathrm{~g}$ of protein maximally stimulates muscle protein synthesis translate into improved muscle and functional outcomes?

\title{
Acknowledgments
}

\author{
None \\ Financial support and sponsorship
}

This research was supported by grants from NIH/NIA R01 AG030070, UTMB Claude D. Pepper Older Americans Independence Center P30 AG024832, and that Dairy Research Institute 1229.

\section{References}

Papers of particular interest published within the annual period of review (2013-2014), have been highlighted as:

* of special interest

** of outstanding interest

1. Cruz-Jentoft AJ, Michel JP. Sarcopenia: A useful paradigm for physical frailty. European Geriatric Medicine. 4(2):102-5.

2. Cruz-Jentoft AJ, Landi F, Schneider SM, Zuniga C, Arai H, Boirie Y, et al. Prevalence of and interventions for sarcopenia in ageing adults: a systematic review. Report of the International Sarcopenia Initiative (EWGSOP and IWGS). Age Ageing. 2014; 43(6):748-59. [PubMed: 25241753]

3**. Studenski SA, Peters KW, Alley DE, Cawthon PM, McLean RR, Harris TB, et al. The FNIH sarcopenia project: rationale, study description, conference recommendations, and final estimates. J Gerontol A Biol Sci Med Sci. 2014; 69(5):547-58. New criteria developed for the diagnosis of sarcopenia based on clinically relevant thresholds. [PubMed: 24737557]

4. Fielding RA, Vellas B, Evans WJ, Bhasin S, Morley JE, Newman AB, et al. Sarcopenia: an undiagnosed condition in older adults. Current consensus definition: prevalence, etiology, and consequences. International working group on sarcopenia. J Am Med Dir Assoc. 2011; 12(4):24956. [PubMed: 21527165]

5. Morley JE, Abbatecola AM, Argiles JM, Baracos V, Bauer J, Bhasin S, et al. Sarcopenia with limited mobility: an international consensus. J Am Med Dir Assoc. 2011; 12(6):403-9. [PubMed: 21640657]

6. Alley DE, Shardell MD, Peters KW, McLean RR, Dam TT, Kenny AM, et al. Grip strength cutpoints for the identification of clinically relevant weakness. J Gerontol A Biol Sci Med Sci. 2014; 69(5):559-66. [PubMed: 24737558] 
7. Cawthon PM, Peters KW, Shardell MD, McLean RR, Dam TT, Kenny AM, et al. Cutpoints for low appendicular lean mass that identify older adults with clinically significant weakness. J Gerontol A Biol Sci Med Sci. 2014; 69(5):567-75. [PubMed: 24737559]

8. Dam TT, Peters KW, Fragala M, Cawthon PM, Harris TB, McLean R, et al. An evidence-based comparison of operational criteria for the presence of sarcopenia. J Gerontol A Biol Sci Med Sci. 2014; 69(5):584-90. [PubMed: 24737561]

9. McLean RR, Shardell MD, Alley DE, Cawthon PM, Fragala MS, Harris TB, et al. Criteria for clinically relevant weakness and low lean mass and their longitudinal association with incident mobility impairment and mortality: the foundation for the National Institutes of Health (FNIH) sarcopenia project. J Gerontol A Biol Sci Med Sci. 2014; 69(5):576-83. [PubMed: 24737560]

10. Correa-de-Araujo R, Hadley E. Skeletal muscle function deficit: a new terminology to embrace the evolving concepts of sarcopenia and age-related muscle dysfunction. J Gerontol A Biol Sci Med Sci. 2014; 69(5):591-4. [PubMed: 24737562]

11. Landi F, Cruz-Jentoft AJ, Liperoti R, Russo A, Giovannini S, Tosato M, et al. Sarcopenia and mortality risk in frail older persons aged 80 years and older: results from ilSIRENTE study. Age and Ageing. 2013; 42(2):203-9. [PubMed: 23321202]

12. Arango-Lopera VE, Arroyo P, Gutierrez-Robledo LM, Perez-Zepeda MU, Cesari M. Mortality as an adverse outcome of sarcopenia. J Nutr Health Aging. 2013; 17(3):259-62. [PubMed: 23459979]

13. Chalé A, Cloutier GJ, Hau C, Phillips EM, Dallal GE, Fielding RA. Efficacy of Whey Protein Supplementation on Resistance Exercise-Induced Changes in Lean Mass, Muscle Strength, and Physical Function in Mobility-Limited Older Adults. The Journals of Gerontology Series A: Biological Sciences and Medical Sciences. 2013; 68(6):682-90.

14. Dickinson JM, Volpi E, Rasmussen BB. Exercise and nutrition to target protein synthesis impairments in aging skeletal muscle. Exerc Sport Sci Rev. 2013; 41(4):216-23. [PubMed: 23873131]

15. Liu CK, Leng X, Hsu FC, Kritchevsky SB, Ding J, Earnest CP, et al. The impact of sarcopenia on a physical activity intervention: the Lifestyle Interventions and Independence for Elders Pilot Study (LIFE-P). J Nutr Health Aging. 2014; 18(1):59-64. [PubMed: 24402391]

16. Beck AM, Kjaer S, Hansen BS, Storm RL, Thal-Jantzen K, Bitz C. Follow-up home visits with registered dietitians have a positive effect on the functional and nutritional status of geriatric medical patients after discharge: a randomized controlled trial. Clin Rehabil. 2013; 27(6):483-93. [PubMed: 23258932]

17. Beasley JM, Shikany JM, Thomson CA. The role of dietary protein intake in the prevention of sarcopenia of aging. Nutr Clin Pract. 2013; 28(6):684-90. [PubMed: 24163319]

18. Cerri AP, Bellelli G, Mazzone A, Pittella F, Landi F, Zambon A, et al. Sarcopenia and malnutrition in acutely ill hospitalized elderly: Prevalence and outcomes. Clin Nutr. 2014

19. Agarwal E, Miller M, Yaxley A, Isenring E. Malnutrition in the elderly: a narrative review. Maturitas. 2013; 76(4):296-302. [PubMed: 23958435]

20. Velazquez Alva Mdel C, Irigoyen Camacho ME, Delgadillo Velazquez J, Lazarevich I. The relationship between sarcopenia,undernutrition, physical mobility and basic activities of daily living in a group of elderly women of Mexico City. Nutr Hosp. 2013; 28(2):514-21. [PubMed: 23822706]

21. Campbell WW, Johnson CA, McCabe GP, Carnell NS. Dietary protein requirements of younger and older adults. Am J Clin Nutr. 2008; 88(5):1322-9. [PubMed: 18996869]

22. Morse MH, Haub MD, Evans WJ, Campbell WW. Protein requirement of elderly women: nitrogen balance responses to three levels of protein intake. J Gerontol A Biol Sci Med Sci. 2001; 56(11):M724-30. [PubMed: 11682582]

23*. Rafii M, Chapman K, Owens J, Elango R, Campbell WW, Ball RO, et al. Dietary Protein Requirement of Female Adults >65 Years Determined by the Indicator Amino Acid Oxidation Technique Is Higher Than Current Recommendations. The Journal of Nutrition. 2014 Details an alternative method, the indicator amino acid oxidation technique, which measures labeled tracer oxidation in expired air in response to different amounts of protein to determine the average minimal amount of protein necessary for nitrogen balance. 
24. Tang M, McCabe GP, Elango R, Pencharz PB, Ball RO, Campbell WW. Assessment of protein requirement in octogenarian women with use of the indicator amino acid oxidation technique. Am J Clin Nutr. 2014; 99(4):891-8. [PubMed: 24429540]

25. Volpi E, Campbell WW, Dwyer JT, Johnson MA, Jensen GL, Morley JE, et al. Is the optimal level of protein intake for older adults greater than the recommended dietary allowance? J Gerontol A Biol Sci Med Sci. 2013; 68(6):677-81. [PubMed: 23183903]

26*. Bauer J, Biolo G, Cederholm T, Cesari M, Cruz-Jentoft AJ, Morley JE, et al. Evidence-based recommendations for optimal dietary protein intake in older people: a position paper from the PROT-AGE Study Group. J Am Med Dir Assoc. 2013; 14(8):542-59. Updated recommendations for optimal dietary protein intake in older adults. [PubMed: 23867520]

27. Deutz NE, Bauer JM, Barazzoni R, Biolo G, Boirie Y, Bosy-Westphal A, et al. Protein intake and exercise for optimal muscle function with aging: Recommendations from the ESPEN Expert Group. Clin Nutr. 2014

28. Paddon-Jones D, Leidy H. Dietary protein and muscle in older persons. Curr Opin Clin Nutr Metab Care. 2014; 17(1):5-11. [PubMed: 24310053]

29. Berner LA, Becker G, Wise M, Doi J. Characterization of Dietary Protein among Older Adults in the United States: Amount, Animal Sources, and Meal Patterns. Journal of the Academy of Nutrition and Dietetics. 2013; 113(6):809-15. [PubMed: 23491327]

30. Clegg A, Young J, Iliffe S, Rikkert MO, Rockwood K. Frailty in elderly people. The Lancet. 381(9868):752-62.

31. Wall BT, Dirks ML, van Loon LJC. Skeletal muscle atrophy during short-term disuse: Implications for age-related sarcopenia. Ageing Research Reviews. 2013; 12(4):898-906. [PubMed: 23948422]

32. Burd NA, Gorissen SH, van Loon LJ. Anabolic resistance of muscle protein synthesis with aging. Exerc Sport Sci Rev. 2013; 41(3):169-73. [PubMed: 23558692]

33. Deutz NE, Wolfe RR. Is there a maximal anabolic response to protein intake with a meal? Clin Nutr. 2013; 32(2):309-13. [PubMed: 23260197]

34. Churchward-Venne TA, Breen L, Phillips SM. Alterations in human muscle protein metabolism with aging: Protein and exercise as countermeasures to offset sarcopenia. Biofactors. 2014; 40(2): 199-205. [PubMed: 24105883]

35*. Mamerow MM, Mettler JA, English KL, Casperson SL, Arentson-Lantz E, Sheffield-Moore M, et al. Dietary Protein Distribution Positively Influences 24-h Muscle Protein Synthesis in Healthy Adults. The Journal of Nutrition. 2014; 144(6):876-80. Study conducted in healthy middle aged adults examining the effects of distribution of dietary protein to maximally stimulate MPS. [PubMed: 24477298]

36. Luiking YC, Deutz NE, Memelink RG, Verlaan S, Wolfe RR. Postprandial muscle protein synthesis is higher after a high whey protein, leucine-enriched supplement than after a dairy-like product in healthy older people: a randomized controlled trial. Nutr J. 2014; 13:9. [PubMed: 24450500]

37. Thalacker-Mercer AE, Drummond MJ. The importance of dietary protein for muscle health in inactive, hospitalized older adults. Ann N Y Acad Sci. 2014

38. Bollwein J, Diekmann R, Kaiser MJ, Bauer JM, Uter W, Sieber CC, et al. Distribution but not amount of protein intake is associated with frailty: a cross-sectional investigation in the region of Nurnberg. Nutr J. 2013; 12(1):109. [PubMed: 23915061]

39. Bouillanne O, Curis E, Hamon-Vilcot B, Nicolis I, Chretien P, Schauer N, et al. Impact of protein pulse feeding on lean mass in malnourished and at-risk hospitalized elderly patients: a randomized controlled trial. Clin Nutr. 2013; 32(2):186-92. [PubMed: 22992307]

40. Houston DK, Nicklas BJ, Ding J, Harris TB, Tylavsky FA, Newman AB, et al. Dietary protein intake is associated with lean mass change in older, community-dwelling adults: the Health, Aging, and Body Composition (Health ABC) Study. Am J Clin Nutr. 2008; 87(1):150-5. [PubMed: 18175749]

41. Beasley JM, LaCroix AZ, Neuhouser ML, Huang Y, Tinker L, Woods N, et al. Protein intake and incident frailty in the Women's Health Initiative observational study. J Am Geriatr Soc. 2010; 58(6):1063-71. [PubMed: 20487071] 
42. Beasley JM, Wertheim BC, LaCroix AZ, Prentice RL, Neuhouser ML, Tinker LF, et al. Biomarker-calibrated protein intake and physical function in the Women's Health Initiative. J Am Geriatr Soc. 2013; 61(11):1863-71. [PubMed: 24219187]

43. Gray-Donald K, St-Arnaud-McKenzie D, Gaudreau P, Morais JA, Shatenstein B, Payette H. Protein intake protects against weight loss in healthy community-dwelling older adults. J Nutr. 2014; 144(3):321-6. [PubMed: 24357473]

44. Gregorio L, Brindisi J, Kleppinger A, Sullivan R, Mangano KM, Bihuniak JD, et al. Adequate dietary protein is associated with better physical performance among post-menopausal women 60 90 years. J Nutr Health Aging. 2014; 18(2):155-60. [PubMed: 24522467]

45. Arciero PJ, Ormsbee MJ, Gentile CL, Nindl BC, Brestoff JR, Ruby M. Increased protein intake and meal frequency reduces abdominal fat during energy balance and energy deficit. Obesity (Silver Spring). 2013; 21(7):1357-66. [PubMed: 23703835]

46. Dong JY, Zhang ZL, Wang PY, Qin LQ. Effects of high-protein diets on body weight, glycaemic control, blood lipids and blood pressure in type 2 diabetes: meta-analysis of randomised controlled trials. Br J Nutr. 2013; 110(5):781-9. [PubMed: 23829939]

47. Tang M, Armstrong CL, Leidy HJ, Campbell WW. Normal vs. high-protein weight loss diets in men: effects on body composition and indices of metabolic syndrome. Obesity (Silver Spring). 2013; 21(3):E204-10. [PubMed: 23592676]

48. Kim C-O, Lee K-R. Preventive Effect of Protein-Energy Supplementation on the Functional Decline of Frail Older Adults With Low Socioeconomic Status: A Community-Based Randomized Controlled Study. The Journals of Gerontology Series A: Biological Sciences and Medical Sciences. 2013; 68(3):309-16. 


\section{Key Points}

- Sarcopenia is a common clinical problem that is becoming of greater concern as the older population continues to grow.

- Mounting evidence suggests that the RDA, designed to prevent deficiency, is inadequate to promote optimal health in older adults.

- New research has focused on the quantity, quality, and timing of protein intake to best stimulate MPS in older adults.

- There remains a need for large, long-term, randomized clinical trials examining whether the positive effects of dietary protein on muscle metabolism seen in acute studies will translate over the long term into gains of muscle mass, function and overall health of older adults. 